\title{
Measuring PV Module Performance at Different Tilt Angles in Southern Iraq Based Simulation
}

\author{
Abadal-Salam T. Hussain \\ Al-Kitab University College, Computer Technical Engineering, Kirkuk, Alton Kupri, Iraq \\ *Corresponding authorE-mail:asth3@yahoo.com
}

\begin{abstract}
This paper presented that how to calculate the tilt angles and solar irradiance on photovoltaic (PV) module in southern Iraq (latitude $30^{\circ} \mathrm{N}$ ). The latitude and day number of the city is taken into account to calculate the tilt angle and solar irradiance by using a mathematical equation. The optimum tilt angles of PV module in southern Iraq are range from $38^{\circ}$ to $84^{\circ}$. The yearly maximum total and average solar irradiance is needed to determine the optimum tilt angle of PV module. The result shows that $50^{\circ}$ of tilt angle is the best performance of PV module in southern Iraq.
\end{abstract}

Keywords: Measurements; PV module; Tilt Angles; Simulation

\section{Introduction}

The demand of using clean energy to produce electricity increases from year to year since production of power using fossil fuel lead to many harm than good to the environment. One of the ways to produce power is from the sun where the light from the sun is absorbed by PV module which is mainly installed at rooftops of factories, government building and houses in southern Iraq. This assignment will study the performance of the PV system with different angle to produce the maximum output power. The levels of the solar radiation captured by PV module are influenced by azimuth and tilt angles.

\section{Research background}

This study purpose is to provide better understanding about which tilt angle effect the performance of PV module and produce maximum output power [1-3]. When module surface and the incident light rays are perpendicular to each other, the power output will be the highest but on a fix tilt; the power output will be dictated by sun's position and tilt angle. The data for solar irradiance are collected for every day in Southern Iraq [4]. This study is focusing on the energy output of a specific tilt angle.

\section{Problem statement and objectives}

The data collected showing the value of solar irradiance for every day in Southern Iraq. The tilt angle needs to be adjusted until meet the right angle to produce maximum output power.

The objectives of this study are to calculate the tilt angle and solar irradiance on photovoltaic module in Southern Iraq city, Southern Iraq which depend on both latitude and day number.

\section{Theoretical analysis}

The common design for solar PV system is grid-tied. The PV module is directly connected to the power grid all the times without used the battery storage[5-6]. This system will generate the electrical power to supply these power to the building needed. Figure 1 shows the connection of PV system design that normally installed at the building. 


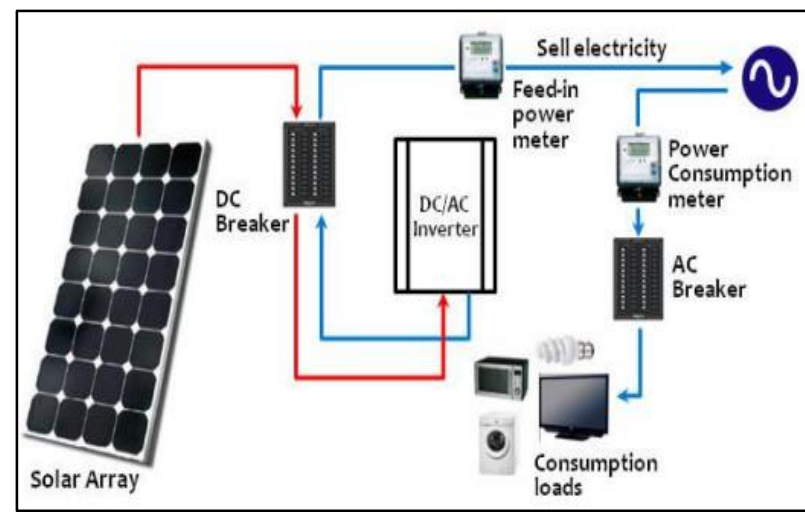

Fig 1: Typical Connection of PV System.

There are several types of PV cells and the best PV cells among others cells is silicon mono-crystalline (SMC) PV [12]. This PV module type is $63 \mathrm{~V}$ and has 216 field wired cells which is connected in three parallel strings and have 72 series of cells in each module. The maximum power of this module that can be produced is $300 \mathrm{~W}$ and its efficiency is not below than $17 \%$. Thus, the SMC-PV module is selected for installation in Southern Iraq.

According to the typical datasheet of SMC-PV modules, the electrical data has assumed for $I_{p h}\left(S_{S}\right)$ is $6.5 \mathrm{~A}$ and $V_{o c}$ is 63.2 V [7]. However, the value of $\mathrm{V}$ and $\mathrm{I}$ that the PV cell have produced is in different operating condition which can be calculated based on the PV cell I-V characteristic equation below. This equation is well known as Shockley equation:

$$
I=I_{p h}-I_{o}\left[\exp \left(\frac{q V}{B T}\right)-1\right]
$$

Where $I_{p h}$ is the photo generated current which is equal to the short circuit $(\mathrm{V}=0), I_{o}$ is reverse saturation of current, $\mathrm{q}$ is constant value of electron charge $\left(\mathrm{q}=1.602 \times 10^{-19}\right), \mathrm{B}$ is the Bolztmann's constant $\left(\mathrm{B}=1.381 \times 10^{-23} \mathrm{~J} / \mathrm{K}\right)$ and $\mathrm{T}$ is the temperature of junction cell.

If the PV cell is left open ( $\mathrm{I}=0)$, the open circuit voltage, $V_{o c}$ can be solved by the equation below:

$$
V_{o c}=\frac{B T}{q} \ln \left(1-\frac{I_{p h}}{I_{o}}\right)
$$

Then, the value of $I_{o}$ can be find since the current $I_{p h}$ is much greater than the $I_{o}$.

$$
I_{o}=I_{p h} \exp \left(-\frac{q V}{B T}\right)
$$

Based on the equation above, the photo generated current, $I_{p h}$ is directly propotional to solar radiation on the PV cell surface. Therefore, the value of $I_{p h}$ at any other insolation, $S_{H}$ is given by

$$
I_{p h}\left(S_{H}\right)=\frac{S_{H}}{S_{S}} I_{p h}\left(S_{S}\right)
$$

In the PV system, the solar radiation is directly converts into electrical energy [14-15]. This energy have generated according to several factor which are intensity, power conversion efficiency, system location, panel installation azimuth, tilt angle, weather conditions and others. Refer to the
Figure 2, the tilt angle is refer to how far up from the horizontal a tilted and azimuth angle represent the direction of celestial object measured clockwise around the observer's horizon from north

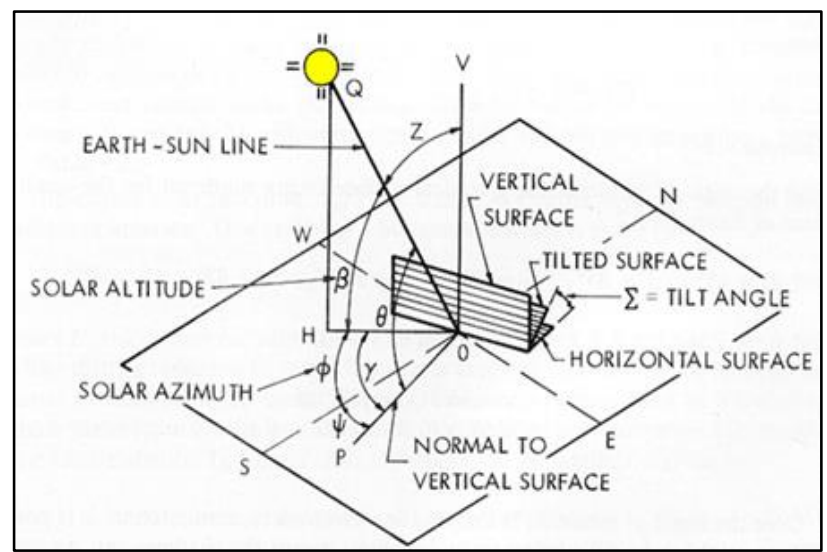

Fig 2: Geometry of Solar Collector.

There are 4 season in Southern Iraq which are winter, spring, summer and autumn. The tilt angle for each season is different. The Figure 3 below shows the graph of output power for different tilt angle which is from $0^{\circ}$ to $90^{\circ}$ in each season for a year.

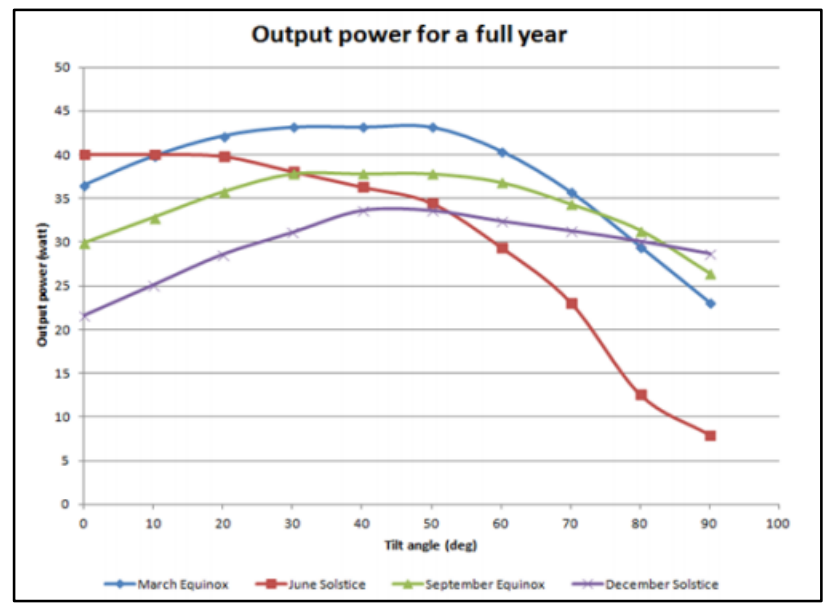

Fig 3: Graph of Output Power versus Tilt Angle in a Year.

Based on the curves, it shows that maximum output power on south facing surface of PV module at noon can be obtained with the tilt angle of $30^{\circ}, 40^{\circ}$ and $50^{\circ}$ with the sun elevation of $60^{\circ}$ at March Equinox which is in spring. Next, the maximum output power at June Solstice (summer), tilt angle is $0^{\circ}, 10^{\circ}$ and $20^{\circ}$ with the sun elevation of $84^{\circ}$ from horizontal, while at September Equinox (autumn), the tilt angle is $30^{\circ}, 40^{\circ}$, and $50^{\circ}$ with sun elevation of $60^{\circ}$ from horizontal. Lastly, at December Solstice (winter), the tilt angle for maximum output power is $40^{\circ}$ and $50^{\circ}$ with the sun elevation of $36^{\circ}$ from horizontal. According to the result above, it shows that the tilt angle of $50^{\circ}$ can be consider as good angle for PV output [8-10].

\section{Solar irradiance}


Total solar irradiance is the amount of radiant energy emitted by the Sun over all wavelengths that fall each second on 11 square feet $(1 \mathrm{sq} \mathrm{m})$ outside the earth's atmosphere. Irradiance is measured at the Earth's surface after atmospheric absorption and scattering [11-3]. Total solar irradiance is a measure of the solar power per unit area normal to the rays, incident on the Earth's upper atmosphere. Irradiance is a function of distance from the Sun, the solar cycle and cross-cycle changes. Irradiance on Earth is most intense at points directly facing the Sun. From this study, it is found that solar irradiation at Southern Iraq is around $2100 \mathrm{~kW} / \mathrm{m}^{2} /$ year.

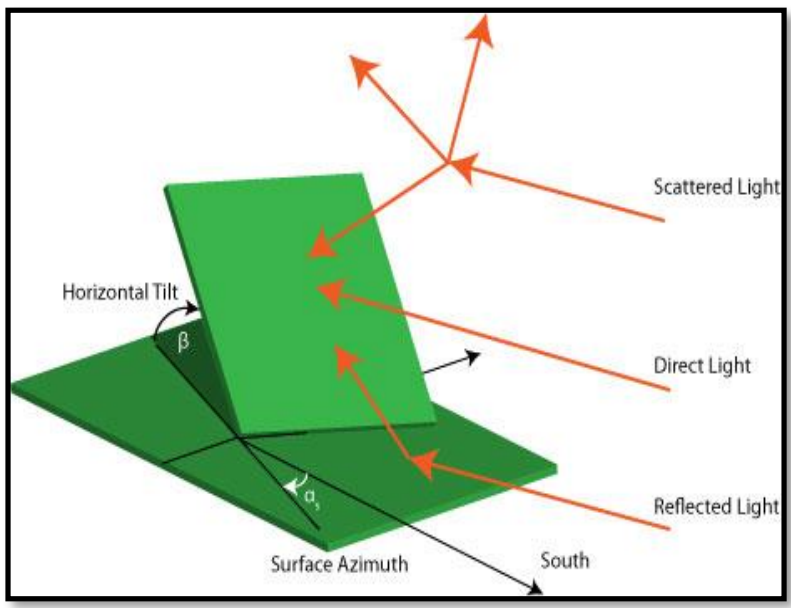

Fig 4: Combination of direct beam, IBT, diffuse, IDT and reflected, IRT equal to solar radiation striking a collector

The formula for total solar irradiance is as below:

Where:

$$
\mathrm{I}_{\mathrm{TT}}=\mathrm{I}_{\mathrm{BT}}+\mathrm{I}_{\mathrm{DT}}+\mathrm{I}_{\mathrm{RT}}
$$

ITT $=$ total solar irradiance on the tilt surface $\left(\mathrm{W} / \mathrm{m}^{2}\right)$

$\mathrm{IBT}=$ total beam solar irradiance absorbed by tilt surface $\left(\mathrm{W} / \mathrm{m}^{2}\right)$

IDT $=$ total diffuse solar irradiance absorbed by tilt surface $\left(\mathrm{W} / \mathrm{m}^{2}\right)$

IRT $=$ total reflected solar irradiance absorbed by tilt surface $\left(\mathrm{W} / \mathrm{m}^{2}\right)$

\section{Tilt angle of a PV module}

Altitude angle is the angular height of the sun measured from the horizontal [2]. Formula for altitude angle at solar noon can be determined according the formula for location in the northern below:

$$
\begin{gathered}
\beta_{\mathrm{N}}=90^{\circ}-\mathrm{L}+\delta \\
\Sigma=90^{\circ}-\beta_{\mathrm{N}}
\end{gathered}
$$

Where:

$\mathrm{L}=$ latitude of the site

$\delta=$ solar declination

$\boldsymbol{\Sigma}=$ tilt angle of PV module

Solar declination, $\delta$ can be determined using the equation below:

$$
\delta=23.45 \sin \left[\frac{360}{365}(n-81)\right]
$$

Where $\mathrm{n}$ is the day number. Figure 5 shows the maximum declination angle.

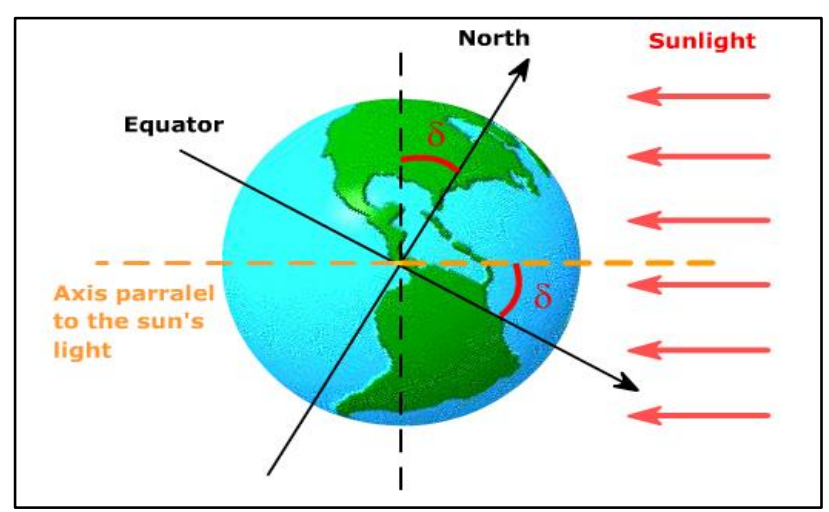

Fig 5: The maximum declination angle $(\delta)$ at solar noon.

From figure 6 shows the collector azimuth angle, $\varnothing_{c}$, solar azimuth angle, $\emptyset s$ and tilt angle $\Sigma$ of the solar panel.

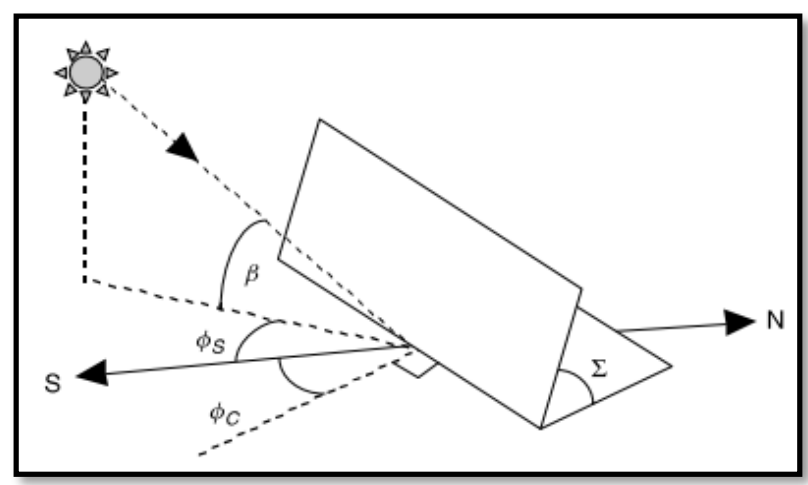

Fig 6: collector azimuth angle, $\varnothing c$, solar azimuth angle, $\emptyset s$ and tilt angle $\Sigma$ of the solar panel.

The formula for $\mathrm{A}, \mathrm{k}$, and $\mathrm{m}$ can be calculated as below:

$$
A=1160+75 \sin \left[\frac{360}{365}(n-275)\right]
$$

$\mathrm{k}=0.174+0.035 \sin \left[\frac{360}{365}(n-100)\right]$

$$
\mathrm{m}=\frac{1}{\sin \beta}
$$

The incidence angle is given by:

$\cos \theta=\cos \beta \cos \left(\emptyset_{s}-\emptyset_{c}\right) \sin \Sigma+\sin \beta \cos \Sigma$

To find solar azimuth angle, $\emptyset s$, we used the formula given:

$$
\sin \emptyset_{s}=\frac{\cos \delta \sin H}{\cos \beta}
$$




\section{Result and discussion}

The optimal angle depends on seasons and locations. In this paper, show the difference in sun height on a month by month. At solar noon, the sun is its zenith and the irradiance will come from it. The solar panel will received more sunlight if they faced it to the south at the optimum angle. Therefore, to get the best angle of solar also depends on when we want to get the best of photovoltaic systems. The best time of to get the best performances is when its time of summer seasons which there is most sunlight but the angle of the panel should be correct according to the height of sun [1]. Below Figure 7 show the graph of tilt angle versus day of the year in Southern Iraq.

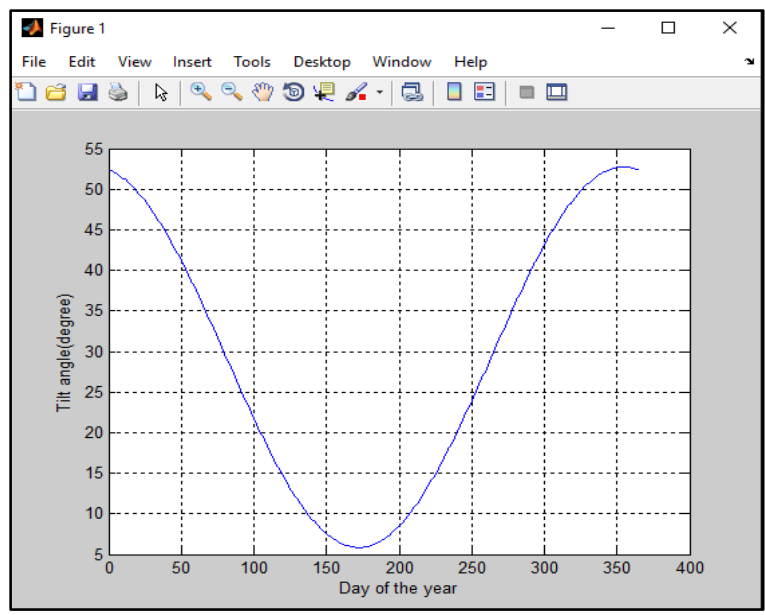

Fig 7: Graph of tilt angle.

The result of the declination has been calculated for 365 days in year 2009 and the latitude is $29.3^{\circ} \mathrm{S}$ in Southern Iraq. From the graph, the $\mathrm{X}$-axis is the day in the number of days since $1 \mathrm{st}$ January 2009 until 31st December 2009 while the Y-axis shows the tilt angle of the PV module. The observation has made from the graft, the tilt angle were changed within a year of 2009 [3]. This is because the coordination of sun is always changing within a year and for Southern Iraq it has four seasons. The coordination of the sun and tilt angle must be sequenced to the PV module because to get the best performance of angle.

Figure 8 shows the total annual solar irradiance of the different tilt angle. The maximum total annual solar irradiance is $3.725 \times 105 \mathrm{~W} / \mathrm{m}^{2}$ at tilt angle $5.85^{\circ}$ and Figure 9 shows the graph of average annual solar irradiance.

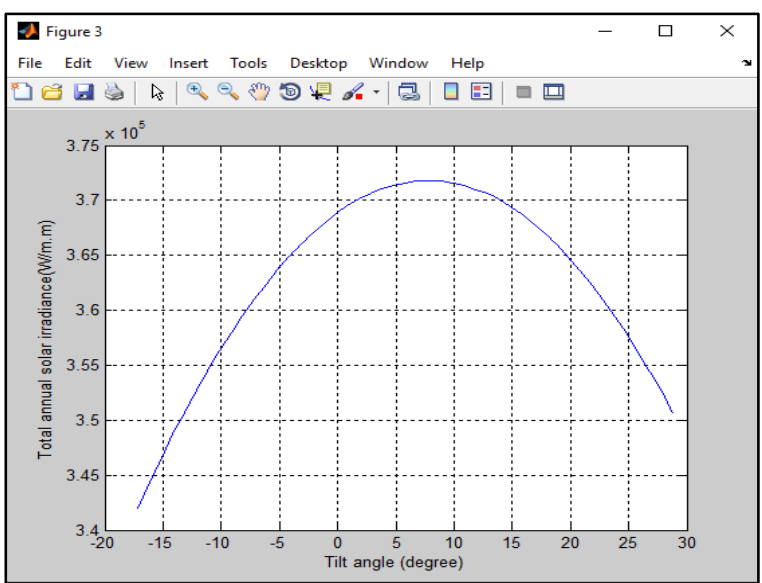

Fig 8: Annually total solar $\left(\mathrm{W} / \mathrm{m}^{2}\right)$.

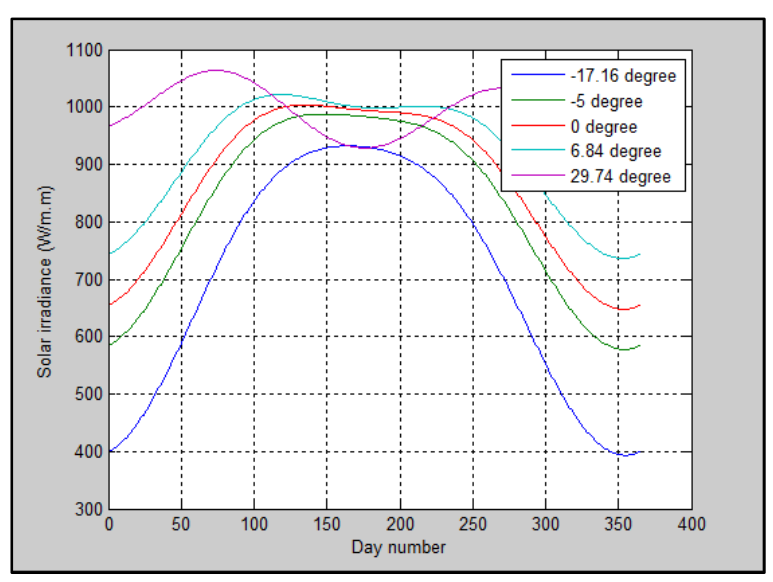

Fig 9: Solar irradiance $\left(\mathrm{W} / \mathrm{m}^{2}\right)$

Based on the Figure 9, it shows the change of solar irradiance by using the different tilt angle which is in degrees through the whole year of 2009 in Southern Iraq. As a result, the solar irradiance increased through the different tilt angle for that year.

For horizontal tilt angle, the minimum value of solar irradiance is $998.2 \mathrm{~W} / \mathrm{m}^{2}$, the maximum value is $1071 \mathrm{~W} / \mathrm{m}^{2}$. For tilt angle $-5^{\circ}$, the minimum value of solar irradiance is $577.7 \mathrm{~W} / \mathrm{m}^{2}$, the maximum value is $987.7 \mathrm{~W} / \mathrm{m}^{2}$ and the average value is $827.9 \mathrm{~W} / \mathrm{m} 2$. Next, tilt angle $6.84^{\circ}$ the minimum solar irradiance is $736.3 \mathrm{~W} / \mathrm{m}^{2}$, the maximum is $1022 \mathrm{~W} / \mathrm{m}^{2}$ and the average is $918.2 \mathrm{~W} / \mathrm{m}^{2}$

For tilt angle $-17.16^{\circ}$, the minimum solar irradiance $393.4 \mathrm{~W} / \mathrm{m}^{2}$, the maximum is $932.1 \mathrm{~W} / \mathrm{m}^{2}$ and the average value is $704.3 \mathrm{~W} / \mathrm{m}^{2}$. Lastly, tilt angle $29.74^{\circ}$, the minimum value solar irrandiance is $928.6 \mathrm{~W} / \mathrm{m}$ and the maximum value is $1064 \mathrm{~W} / \mathrm{m}^{2}$ and the average value is $995.6 \mathrm{~W} / \mathrm{m}^{2}$.

Based on Figure 10 shows the graph of clear sky global solar irradiance versus day of the year. From the graph shows the line graph of clear sky global solar irradiance always change because of four seasons that happens in Southern Iraq over a year of 2009. 


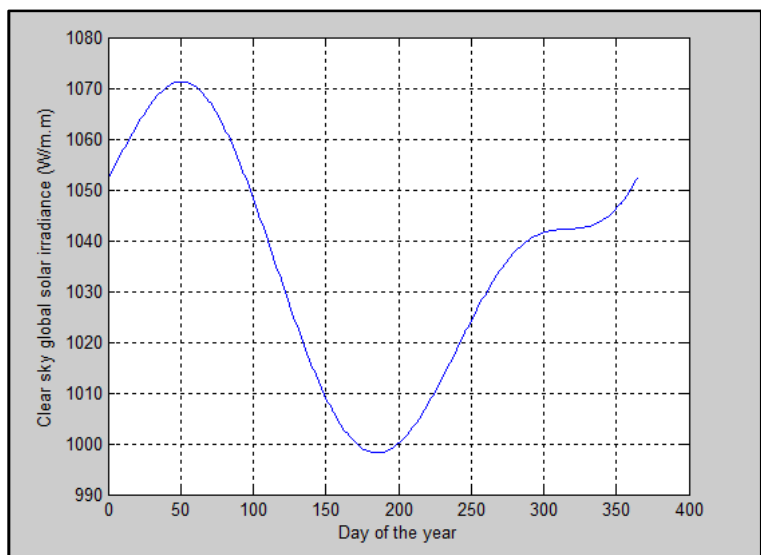

Fig 10: Show the graph of clear sky global solar irradiance $\left(\mathrm{W} / \mathrm{m}^{2}\right)$

\section{Conclusion}

In the nutshell, in order to solve insufficient power supply capabilities and high peak loadings in Southern Iraq, the solar energy availability in Southern Iraq area are suitable to use as a resource from the investigation. Different tilt angles of PV module will affect the solar irradiance. The daily and monthly tilt angle on the surfaces Southern Iraq area has been recorded, and the range is between $-17.16^{\circ}$ to $29.74^{\circ}$.

The optimum tilt angle of PV module on 1st 110 days is $29.4^{\circ}$ , after 110 days, the optimum tilt angle is $6.84^{\circ}$ until 225 days the optimum tilt angle need change back to $29.4^{\circ}$. Based on the result, it showed a clear indication of the visibility and potential of solar energy used in Southern Iraq.

From the data recorded, the maximum clear sky global solar irradiance in the year 2009 is $1070 \mathrm{~W} / \mathrm{m}^{2}$ on $1 \mathrm{st} 50$ days of the year whereas the minimum of the irradiance is $918 . \mathrm{W} / \mathrm{m}^{2}$ on 175 days.

\section{Acknowledgement}

Thanks for Alkitab University College for providing the financial support and practical facilities to achieve this project.

\section{References}

[1]. Solar Panel Tilt Calculator [Online]. Available: http://www.gogreensolar.com

[2]. What are the factors affecting Solar Radiation [Online]. Available: http:/www.innovateus.net/science/what-are-factorsaffecting-solar-radiation

[3]. Mohammed A. Bou-Rabee, "On Seasonal Variation of Solar Irradiation in Southern Iraq," PAAET Dept. of Electrical Eng. College of Technological Studies Southern Iraq, Southern Iraq, 2015.

[4]. Chang YP. Optimal the tilt angles for photovoltaic modules in Taiwan. Journal of Electrical Power and Energy Systems. 2010, 1-9.

[5]. Kacira M, Simsek M, Babur Y, Demirko S. Determining optimum tilt angles and orientations of photovoltaic panels in Sanliurfa, Turkey. Journal of Renewable Energy. 2004:29:1265-1275.

[6]. Mahmoud M, Nabhan I. Determination of optimum tilt angle of single and multi-rows of photovoltaic arrays for selected area in Jordan. Journal of Solar \& Energy. 7:739-745.
[7]. Masters GM. Renewable and efficient electric power systems. New Jersey: John Wiley \& Sons, Inc. 2004.

[8]. Yorukoglu M, Celik AN. A Critical Review on the Estimation of Daily Global Solar Radiation from Sunshine Duration", Energy Conversion \& Management. 2006, 2441-2450.

[9]. Kuin TH, Ramsey W, Threlkeld JL. Thermal environment Engineering. Prentice-Hall, Englewood Cliffs, NJ, 1998.

[10]. Pandey CK. A note on diffuse solar radiation on a tilted surface. Journal of Energy. 34, 1764-1769.

[11]. Daut I, Sembiring M, Irwanto M, Syafawati N, Hadi S. Solar Radiation Potential for Photovoltaic Power Generation Based on Meteorological Data in Perlis. International Conference: Electrical Energy and Industrial Electronic Systems EEIES2009, Penang, Malaysia. 2009.

[12]. Hussain, T. (2014). Model Predictive Controller-based, Single Phase Pulse Width Modulation (PWM) Inverter for UPS Systems. Acta Polytechnica Hungarica, 11(6).

[13]. Saleh, N., Mushtaq, K., Zaidi, A. A., Abbasoglu, S., \& Ahmed, S. F. (2016). Design and Performance Analysis of a Solar Powered Hybrid Rickshaw for Commercial Use in Pakistan. J Environ Sci Technol, 9, 472-80

[14]. Ahmed, S. F., Desa, H., Azim, F., Surti, A., \& Hussain, W. (2013, April). Remote access of SCADA with online video streaming. In Computer Science \& Education (ICCSE), 2013 8th International Conference on (pp. 270-274). IEEE.

[15]. Ahmed, S. F. (2007, December). A new approach in Industrial automation application" Embedded system design for Injection Molding Machine". In Multitopic Conference, 2007. INMIC 2007. IEEE International (pp. 1-5). IEEE 